$\begin{array}{ll} & \text { Etnográfica } \\ \text { etnográfica } & \text { Revista do Centro em Rede de Investigação em }\end{array}$

Antropologia

vol. 25 (3) | 2021

Vol. 25 (3)

\title{
Pelo prazer da Antropologia, do Conhecimento e da Leitura
}

\section{Humberto Martins}

\section{OpenEdition \\ Journals}

Edição electrónica

URL: https://journals.openedition.org/etnografica/10578

DOI: 10.4000/etnografica. 10578

ISSN: 2182-2891

\section{Editora}

Centro em Rede de Investigação em Antropologia

\section{Edição impressa}

Data de publição: 1 outubro 2021

Paginação: 559-560

ISSN: 0873-6561

\section{Refêrencia eletrónica}

Humberto Martins, «Pelo prazer da Antropologia, do Conhecimento e da Leitura», Etnográfica [Online], vol. 25 (3) | 2021, posto online no dia 29 outubro 2021, consultado o 09 janeiro 2022. URL: http:// journals.openedition.org/etnografica/10578; DOI: https://doi.org/10.4000/etnografica.10578

\section{(c) (7) (8)}

Etnográfica is licensed under a Creative Commons Attribution-NonCommercial 4.0 International License. 


\section{Pelo razer da Antropologia, do Conhecimento e da Leitura}

\section{Humberto Martins}

MARTINS, Humberto (humbmsm@yahoo.com) - UTAD, UMinho, CRIA, Portugal

ASSUMO AGORA E EM CONJUNTO COM OUTRAS DOZE PESSOAS (Antonádia Borges, Chiara Pussetti, Cyril Isnart, Diana Espírito Santo, Emília Margarida Marques, Inês Ponte, José Antonio Cortés Vázquez, Luís Cunha, Maria Cardeira da Silva, Octávio Sacramento, Renata Sá Gonçalves, Ruy Blanes) a Comissão Editorial da Etnográfica. Não esquecendo a Mónica Rodrigues (assistente editorial), o renovado Conselho Consultivo Internacional, bem como todas as outras pessoas que na sombra tornam possível a sua existência em papel e digital - revisor, paginador, grafismo, integração, colocação e seguimento online. Não será tarefa fácil nesta aventura colectiva de autores, leitores, editores, conselheiros e pareceristas. O legado é pesado porque anteriormente vários colegas fizeram muito bem as coisas e a Revista tem uma história que fala por si. Neste particular, um enorme e devido agradecimento a Manuela Ivone Cunha, que nos últimos seis anos liderou com sageza, clarividência e sensatez a Revista, consolidando o caminho daquela que é uma referência da literatura em ciências sociais em Portugal e no espaço lusófono. Já antes, João Leal e Miguel Vale de Almeida tinham, nesta mesma função, contribuído enormemente para o nascimento e a "vida" desta publicação que tanto Mundo tem dado a conhecer (ver, para uma breve história da Etnográfica, o Editorial assinado pelos três em 2017 aquando da celebração do vigésimo aniversário da revista). ${ }^{1}$

1 João Leal, Miguel Vale de Almeida e Manuela Ivone Cunha, 2017, "Parabéns Etnográfica", Etnográfica, 21 (3), online desde 22 março 2018. Disponível em < http://journals.openedition.org/etnografica/4974 > ; DOI: < https://doi.org/10.4000/etnografica.4974 > (última consulta em outubro de 2021). 
A Etnográfica, tal como se anuncia no seu âmbito editorial, é uma revista de Antropologia Social e Cultural que tem por objectivo dar espaço privilegiado (mas não único) à etnografia. Define-se a "diversidade de contextos etnográficos, a qualidade da pesquisa empírica, a diversidade de perspectivas analíticas e a inovação teórica" numa escrita admitida em quatro idiomas (Português, Espanhol, Francês e Inglês) como critérios de referência para informar os autores (e os leitores). Seguiremos este caminho, em tempos que nos mostram valorizações diversas, mas tantas vezes descuidadas, da etnografia, e depreciações também múltiplas da antropologia e das ciências sociais em geral. Neste percurso, procuraremos também dar espaço a outros formatos (de escrita ou audiovisuais) que assegurem dois outros pressupostos fundamentais - o do bom conhecimento e o do prazer da leitura (ou espectadoria).

Esses serão importantes desafios da Etnográfica. Não deixar silenciar a Antropologia e as Ciências Sociais. Ao mesmo tempo que apontamos a novas e renovadas geografias de escrita e leitura e a novas "modalidades etnográficas" de representação, assegurando que o Mundo, nas suas sempre emergentes, desconhecidas ou silenciadas diversidades, seja mais conhecido e reconhecido. É seguramente um dos caminhos que queremos percorrer. Descobrir, chegar a novos autores e leitores, alargando o universo referencial de uma Revista que se quer inclusiva, criativa, inspiradora, aberta a desafios, como o digital, sem nunca abandonar o seu propósito original - o conhecimento cuidado da vida das pessoas, das suas relações, interacções entre si e com as coisas e tudo o resto. Até porque, e como bem sabemos, a vida é feita e vivida desigualmente, assim como são os acessos e as possibilidades de dizê-lo, contá-lo e conhecê-lo. E também aqui cabe à Etnográfica uma responsabilidade editorial e política no âmbito do que poderíamos designar por diversidade epistemológica. 